\title{
Impact of Financial Leverage on Cash Flow Ratio: A Comparative Study Between MNCs and Domestic Companies Listed on DSE
}

\author{
Syed Mohammad Khaled Rahman ${ }^{1}$, Md. Tahidur Rahman ${ }^{2, *}$ \\ ${ }^{1}$ Department of Business Administration, Shahjalal University of Science \& Technology, Sylhet, Bangladesh \\ ${ }^{2}$ Department of Business Administration, EXIM Bank Agricultural University Bangladesh, Chapainawabganj, Bangladesh
}

Email address:

Kr15sust@gmail.com (S. M. K. Rahman), towhidais@gmail.com (Md. T. Rahman)

*Corresponding author

\section{To cite this article:}

Syed Mohammad Khaled Rahman, Md. Tahidur Rahman. Impact of Financial Leverage on Cash Flow Ratio: A Comparative Study Between MNCs and Domestic Companies Listed on DSE. Journal of Finance and Accounting. Vol. 5, No. 5, 2017, pp. 177-184. doi: $10.11648 /$ j.jfa.20170505.11

Received: June 20, 2017; Accepted: September 6, 2017; Published: October 16, 2017

\begin{abstract}
Financial structure decisions have strategic role on owners' welfare and also on survival of companies. Every company is supposed to maintain its optimum capital structure, although its measurement is very difficult. Based on secondary data the study intends to analyze and compare the impact of financial leverage on cash flow ratio of Multinational Companies (MNCs) and domestic companies listed on the Dhaka Stock Exchange (DSE) over a period of 20 years starting from 1996 to 2015. A total of 14 companies consisting of seven MNCs and equal number domestic companies were selected as sample from six industrial sectors. The explained variable of the study was Cash flow ratio (CFR), whereas the explanatory variables were indicators of financial leverage such as: Debt to assets ratio (TD/TA), Debt to equity ratio (TD/SE) and Debt to capital employed ratio (TD/CE). The study has found that Debt to asset ratio is positively related but Debt to equity ratio is negatively related with CFR in domestic companies. A mere 1\% increase in Debt to asset ratio and Debt to equity ratio result in $0.501 \%$ increase and $0.03 \%$ decrease of CFR respectively. In MNCs, unlike domestic companies, Debt to asset ratio is negatively related, whereas Debt to equity ratio is positively related with CFR. For $1 \%$ increase of Debt to equity ratio, CFR decrease by $1.5 \%$ and vice-versa. On the other hand, for $1 \%$ increase in Debt to equity ratio, CFR increases by $0.0039 \%$ and vice-versa. The study concludes that financial leverage ratios have significant influence on cash flows of domestic companies but not on cash flows of MNCs in Bangladesh.
\end{abstract}

Keywords: Capital Structure, Leverage, Equity, Cash Flow Ratio

\section{Introduction}

Financial structure, commonly known as capital structure, is the proportion or composition of debt and equity. Choosing the appropriate financial structure is a critical decision for any business organization. The decision is very important not just because of its necessity to maximize shareholder's wealth or to increase the market value of companies but for the impacts such decisions have on the company's ability to deal with the competitive environment through satisfactory financial performance. Financial structure decisions have a strategic role on welfare of owners and also on survival of the companies. The prime objective of this decision is to keep financing cost at the minimum level with maximum utilization of funds for maximizing profit. Financial leverage decisions are also very important for firms to ensure the maximum returns to their stockholders. The global financial crisis that hit the world economy during 2007-08 had brought the most significant economic recession. Many corporate giants went bankrupt during the period and a significant reason behind the bankruptcy was excessive use of debt capital or borrowing. In order to enjoy the advantages of tax shield and also to improve earnings per share many companies raise too much debt capital which is sometimes 
detrimental to their good performance and survival. Excessive use of debt capital leads to financial distress whereas excessive use of equity capital leads to poor financial performance and low company value. Developing countries, in fact, view capital market as the engine for future growth through mobilization of surplus fund to the deficit group. It is especially applicable in a country like Bangladesh, where savings is minimal and capital market can no wonder be a lucrative source of finance. Bangladesh having its target to become a middle income country must have significant level of rise in investment, which at the present state of banking system cannot be met. The main objective of the study was to investigate and compare the impact of financial leverage on cash flow ratio of Multinational Companies (MNCs) and domestic companies listed on the Dhaka Stock Exchange (DSE).

\section{Literature Review}

Siddiqui and Rahman [1] in their study attempted to present a comparison of capital structures between MNCs and local blue chip companies listed on the DSE. The study found that capital structures of firms depend on the industry within which they operate. Islam and Islam [2] had studied on the linkage between capital structure and profitability of North Bengal Paper Mills Limited in Bangladesh. The study found adverse effect of unfavorable debt-equity ratio on the profitability of the company measured in terms of return on capital employed (ROCE) and return on investment (ROI). Chowdhury and Chowdhury [3] conducted their study to analyze the impact of capital structure on the value of Bangladeshi firms. The study found a strong positive association between stock price and leverage ratio. The work of Islam, Rahman and Khan [4] revealed that profitability and risk played significant role in explaining the capital structure of cement industry in Bangladesh. Hasan, Ahsan, Rahaman and Alam [5] in their study investigated the influence of capital structure on firm's performance. They found that EPS was significantly positively related to short term debt while significantly negatively related to long term debt.

Huq [6] performed a study on the comparative analysis of leverage of some public and private sector chemical industries in Bangladesh during 1994-95 to 2000-01. The study also revealed that the financial leverage had produced negative significant impact on both the EPS and Return on Investment (ROI) of the enterprises during the study period. Uddin, Hossain and Abdullah [7] had undertaken a research on capital structure of DSE listed companies to analyze the effect of Debt to Asset Ratio (DAR) on risk and return of shareholders' stock. They found that DAR had insignificant positive correlation with the average stock returns. Ahmed [8] analyzed financial structure of four insurance companies to measure performance during 1999-2003. Study found that Green Delta Insurance Company had high level of D/E ratio and had satisfactory level in ROE, ROA, net profit and ROI.

Modigliani and Miller [9] introduced the term capital structure, argued that capital structure was irrelevant in determining the firm's value. Many studies such as Lubatkin and Chatterjee [10] have found the existence of a relationship between capital structure and firm value. According to Apergis and Sorros [11], large firms with few growth options have more long-term debt in their capital structure. The work of Muscettola [12] revealed a significant positive relationship between borrowed capital and likelihood of default. Barakat [13] conducted a study aimed at investigating the effect of financial structure, financial leverage, and profitability on company's value. He concluded that there was statistically significant direct relationship between return on equity and capital structure. Fama and French [14] found that there was negative relationship between debt and financial achievement.

Park and Jang [15] in their study jointly investigated the inter-relationships among capital structure, free cash flow, diversification and firm performance. This study found that debt leverage is an efficient way to reduce free cash flows and enhance firm performance. Mansourlakoraj and Sepasi [16] attempted to investigate the relationship between the free cash follow and capital structure and value of listed companies in Tehran Stock Exchange. Findings showed that free cash flow and capital structure have significant and positive effects on firm value. Kordlouie, Mosadegh and Rad [17] examined the impact of cash flow on capital structure of firm. Results revealed that as it was expected there is significant relationship between operational cash flow and external financing for the firm listed at Tehran stock exchange. Nahr and Nemati [18] investigated the relationship between financial performances, free cash flow, capital structure and diversification. Study found that there is no significant relationship between capital structure and free cash flow. Khan, Kaleem and Nazir [19] examined how manufacturing sector of Pakistan mitigate the agency cost of free cash flow by using leverage. Results revealed that the firm leverage play an important role in reducing the agency cost of free cash flow by reducing the free cash flow that is under the control of the manager. Soumaya [20] analyzed the effect of the debt, liquidity and firm size on the investmentcash flow sensitivity on 82 French firms. Study revealed that the debt has a negative effect on the investment-cash flow sensitivity

Some research works in Bangladesh have been conducted covering the issues like pattern of capital structure, agency relationship, determinants of capital structure, impact of leverage on market price of shares, bankruptcy costs etc. Based on the existing literatures available online and other sources, no research work has been found comparing MNCs and domestic companies in terms of impact of financial leverage on financial performance.

\section{Objective of the Study}

In an effort to fill up the research gap, the main objective of the research is to analyze and compare the impact of financial leverage of DSE-listed MNCs and domestic 
companies on cash flow ratio over a 20-year period (19962015). The specific objectives are:

a. To explore the change of cash flow ratio for change in financial leverage ratios of $\mathrm{MNCs}$ and domestic companies listed on the DSE.

b. To identity whether the impact of financial leverage ratios on cash flow ratios are statistically significant for MNCs and domestic companies.

\section{Methodology of the Study}

\subsection{Nature of the Study, Sources of Data and Time Reference}

The current study is an explanatory one that have followed the quantitative approach to identify the cause-effect relationship between financial leverage and cash flow ratio of MNCs and domestic companies listed on the DSE. The research is completely based on secondary data. Both time series and cross sectional data pertain to the study period of 20 years from 1996 to 2015 have been analyzed using different quantitative tools. The major sources of information for the study are Journals, Company documents, Annual reports of sample firms, Reports of Securities and Exchange Commission \& Dhaka Stock Exchange (DSE), and Websites of sample firms and DSE.

\subsection{The Population}

Two sets of population have been used in the current study. Set one consists of all MNCs listed on the DSE that were in operation during the study period. There were eight MNCs in six industrial sectors. Set two consists of all DSE listed domestic companies of the same six industrial sectors that were continuing their operations during the study period. Thus, the population size of set tow stood at 45 .

\subsection{Sample Companies}

Each of the two populations has been divided into six strata according to their industry category. As the study was a comparative one, the numbers of domestic blue chip companies were kept equal to the number of MNCs in any particular industry category. For the sake of comparison with the MNCs, it was necessary to select only those domestic companies that were performing well on a consistent basis. Following stratified and quota sampling method, 7 MNCs and 7 local firms listed on DSE have been selected respectively. Although the number of sample companies in each population is 7 , but total observation is $7 \times 20=140$ as study period is 20 years for each firm. So, a meaningful logical conclusion can be drawn by the observed data. Four companies were selected from Pharmaceuticals \& Chemicals sector and two companies were selected from each of the Engineering, Food \& Allied, Tannery, Cement, and Fuel\& Power sector. Sample of the domestic companies consisted of Beximco Pharmaceuticals Ltd., Square Pharmaceuticals Ltd., Aftab Automobiles Ltd., Agricultural Marketing Company Ltd. (Pran), Apex Footwear Ltd., Confidence Cement Ltd., and Padma Oil Company Ltd. On the other hand, sample of MNCs included GlaxoSmithKline (Bangladesh) Ltd., Reckitt Benckiser (Bangladesh) Ltd., Singer (Bangladesh) Ltd., British American Tobacco Bangladesh Company Ltd., Bata Shoe Company Ltd., Heidelberg Cement Bangladesh Ltd., and Linde Bangladesh Ltd.

\subsection{Tools and Techniques for Data Analysis}

Descriptive statistics such as mean has been used to determine yearly average and grand average. For multiple regression analysis, Ordinary Least Square (OLS) regression method has been applied. Same model has been developed and applied for both the population. Several tests have also been done to evaluate the fitness of the models. Collected data have been processed with the help of MS Excel, SPSS, Statgraphics and Gretl software.

\subsection{Limitations}

The study has been kept restricted to financial data of the firms listed on DSE during a 20 years period starting from 1996 to 2015 . The main limitation of the study is that it does not consider any data beyond the period 1996 to 2015 as well as unlisted companies or companies listed on other stock exchange. Moreover, ending dates of annual accounting period of the sample companies were not the same, which sometimes might create problem in comparison. Number of sample firms was restricted to 7 for each population.

\subsection{Explanation of the Variables and the Regression Model}

Cash flow ratio is the dependent or explained variable of the study which is computed as net cash flow divided by total assets. The independent or explanatory variables of the study consist of three financial leverage ratios, twelve other company specific variables, and two macro-economic variables. Financial Leverage Variables covered Debt to Assets ratio (TD/TA), Debt to Equity ratio (TD/SE) and Debt to Capital Employed ratio (TD/CE) have been used as indicators of financial leverage and also the independent variables of interest.

Company-specific Variables included Firm Size (FS), Firm Age (FAg), Sales Growth (SG), Public Ownership (PO), Tangibility ratio (Tan), Dividend Payout ratio (DP), Marketing and Selling expense ratio (MSE), International Diversification (ID), Management Efficiency (MEf), and Working Capital ratio (WC) have been used as company specific independent variables. Growth rate of GDP (GDP) and Inflation rate (INF) have been taken as macro-economic variables in the model. Macro-economic variables have been incorporated on the assumption that these variables have significant influence on cash flow of companies.

Considering all the aforesaid variables the model stood as under:

$\mathrm{CFR}_{\mathrm{t}}($ Cash Flow Ratio $)=\alpha_{0}+\beta_{1} \mathrm{TD} / \mathrm{TA}+\beta_{2} \mathrm{TD} / \mathrm{SE}+$ $\beta_{3} \mathrm{TD} / \mathrm{CE}+\beta_{4} \mathrm{FS}+\beta_{5} \mathrm{FAg}+\beta_{6} \mathrm{SG}+\beta_{7} \mathrm{PO}+\beta_{8} \mathrm{Tan}+\beta_{9} \mathrm{DP}+$ $\beta_{10} \mathrm{MSE}+\beta_{11} \mathrm{ID}+\beta_{12} \mathrm{MEf}+\beta_{13} \mathrm{WC}+\beta_{14} \mathrm{GDP}+\beta_{15} \mathrm{INF}+\varepsilon$ 
Where: $\alpha_{0}=$ Constant term, $\beta_{1}$ to $\beta_{15}=$ Coefficients of variables, $\varepsilon=$ Random error term.

\section{Data Analysis and Findings}

\subsection{Test of Stationarity of Data}

Augmented Dickey Fuller test, as shown in Table A1 and Table A2, has been done to test stationarity. Second difference has been taken to achieve stationarity for modelsDomestic (CFR) and MNC (CFR). In case of MNCs, as leverage ratios become stationary at $2^{\text {nd }}$ difference level, the same $\left(2^{\text {nd }}\right.$ difference of all the independent and dependent variables) has been taken to maintain unique order in regression.

\subsection{Specification of Models}

Models are denoted as D for domestic companies and as $\mathrm{M}$ for MNCs. For each model 15 explanatory variables (including 3 leverage ratios) were regressed against one explained variable. Backward stepwise method has been applied for selection of models in which variables are removed one by one. Models with highest adjusted $\mathrm{R}$ square were selected. It is seen from Table A3 that in selecting models D (CFR) and M (CFR), model no. 3 and 8 were selected respectively from their set of alternative models.

\subsection{Fitness of Models}

\subsubsection{Test of Multicollinearity}

The measures taken to remove multicollinearity problem of model D\&M have been shown in Table A4 \& A5. After taking the measures all the VIF values became less than 10 . Thus, there was no multicollinearity problem after taking corrective measure.

\subsubsection{Test of Normality}

Kolmogorov-Smirnov, Shapiro-Wilk and chi square test have been performed to test the normality of residuals. Table A6 shows normality test. It is evident from the table that $p$ values of all three measurements in all the models are $>0.05$, which means that residuals are normally distributed.

\subsubsection{Test of Heteroscedasticity}

Breusch-Pagan test has been performed to test heteroscedasticity of residuals. It is seen in Table A7 that $p$ values of all the models' LM test statistic are greater than 0.05 which means that there is no heteroscedasticity of residuals.

\subsubsection{Test of Autocorrelation}

Durbin-Watson (DW) statistic has been used to detect autocorrelation among residuals. The value of DW statistic is between 0-4 and no decision regarding autocorrelation can be made if DW statistic is between $d_{u}$ and $d_{L}$ or between $4-d_{u}$ and $4-d_{L}$. Due to inconclusiveness of DW statistic, BreuschGodfrey test (also called LM test) has also been used to detect autocorrelation. Table A8 shows that autocorrelation among residuals under both DW and LM test. BreuschGodfrey test shows that models do not suffer from autocorrelation problem as $\mathrm{p}$ value of LM test of all models is greater than 0.05 .

\subsubsection{Overall Fitness of the Models}

It is seen in the Table A9 that P-value of F statistic is less than 0.05 in both the models. Therefore, it can be said that there is statistically significant relationship between the variables at the $95.0 \%$ confidence level. From the table, it is seen that independent variables explain more than $95 \%$ and $70 \%$ variability in dependent variables of domestic companies and MNCs respectively.

\subsection{Estimates of the Models}

\subsubsection{Model D (CFR)}

The coefficient Table A10 shows the results of fitting a multiple linear regression model to describe the relationship between dd_CFR and 11 independent variables. The equation of the fitted model is:

$$
\begin{aligned}
& \text { dd CFR }=-0.087-9.552 * \text { dd Tan }+215.385 * \text { dd MSE - } \\
& 2 \overline{42} .961 * \text { dd MEF }-12.373 * \bar{d} d \mathrm{DP}+30.608 * \mathrm{~d} \overline{\mathrm{d}} \mathrm{PO}- \\
& 28.968 * \text { dd ID }+71.3684 * \text { dd NWC }+0.375 * \text { dd } \overline{\text { GDP }} \text { - } \\
& 1.583 * \mathrm{dd} \text { INF }+0.50161 * \mathrm{dd} \text { TD/TA }- \\
& 0.03022 * d d+T D / S E\left(d d \_v a r i a b l e ~=2^{\text {nd }} \text { difference of variable }\right)
\end{aligned}
$$

Debt ratio (TD/TA) is positively related but debt to equity ratio is negatively related with CFR. $1 \%$ increase of $2^{\text {nd }}$ difference of debt ratio results in $0.501 \%$ increase of $2^{\text {nd }}$ difference of CFR. $1 \%$ increase of $2^{\text {nd }}$ difference of debt-equity ratio results in $0.03 \%$ decrease of $2^{\text {nd }}$ difference of CFR.

\subsubsection{Model M (CFR)}

Table A11 shows the results of fitting a multiple linear regression model to describe the relationship between $2^{\text {nd }}$ difference of CFR and 7 independent variables. The equation of the fitted model is:

$$
\begin{aligned}
& \text { dd CFR }=-0.563+0.00399 * \text { dd TD/SE - } \\
& 1.50231 * \text { dd_TD } / \mathrm{TA}+84.964 * \text { dd_FS }-218.608 * \mathrm{dd} \text {-PO }+ \\
& 6.056 * \text { dd_DP }+197.939 * \text { dd_Tan }+0.00045 *\left(1 / \mathrm{dd} \_\overline{\mathrm{T}} / \mathrm{CE}\right) \\
& \left(\text { dd_variable }=2^{\text {nd }} \overline{\text { difference of variable })}\right.
\end{aligned}
$$

Debt ratio (TD/TA) is negatively related but debt to equity ratio is positively related with CFR. For $1 \%$ increase of $2^{\text {nd }}$ difference of debt ratio, $2^{\text {nd }}$ difference of CFR would decrease by $1.5 \%$ and vice-versa. On the other hand, for $1 \%$ increase of $2^{\text {nd }}$ difference of debt-equity ratio, $2^{\text {nd }}$ difference of CFR increases by $0.0039 \%$ and vice-versa. If $2^{\text {nd }}$ difference of reciprocal of debt to capital ratio is increased by $1 \%$ then $2^{\text {nd }}$ difference of CFR would increase by $0.00045 \%$ and vice-versa.

\subsection{Comparison of Effect of Leverage Ratios}

Figures with parenthesis in the Table 1 indicate negative relationships whereas figures without parenthesis indicate positive relationships between leverage ratios and cash flow ratio. It has been seen that ash flow ratios of MNCs are more sensitive than that of domestic companies for a particular change in financial leverage ratio. 
Table 1. Effect of Leverage Ratios on Cash Flow Ratio.

\begin{tabular}{lllllll}
\hline \multirow{2}{*}{ Change in Financial Performance } & \multicolumn{4}{l}{ Change of Domestic companies' leverage ratio by $1 \%$} & \multicolumn{2}{l}{ Change of MNCs' leverage ratio by 1\% } \\
\cline { 2 - 7 } & TD/TA & TD/SE & TD/CE & TD/TA & TD/SE & TD/CE \\
\hline CFR $(\%)$ & 0.501 & $(0.03)$ & & $(1.5)$ & $(0.0039)$ \\
\hline
\end{tabular}

Source: Derived from DSE and Annual Reports of Sample Firms (1996-2015)

Note: Data have been compiled by researcher and calculations made on SPSS and Statgraphics

\subsection{Test of Hypothesis}

Hypothesis $\left(\mathrm{H}_{0}\right)$ of the study is as follows:

Financial leverage does not significantly influence firm's cash flow
This hypothesis has been tested by analyzing the coefficients of financial leverage ratios of the models discussed above. Table 2 shows hypothesis test of both types of companies.

Table 2. Test of Hypothesis $\left(H_{0}\right)$.

\begin{tabular}{llllll}
\hline Leverage \& Performance ratios & Difference & Coefficient & t statistic & p value & Decision regarding $\mathbf{H}_{\mathbf{0}}$ hypothesis \\
\hline Domestic Companies & & & & & \\
CFR \& TD/TA & $2^{\text {nd }}$ & 0.50161 & 4.493 & .006 & Rejected \\
CFR \& TD/SE & $2^{\text {nd }}$ & -0.03022 & -6.103 & .002 & Rejected \\
MNCs & & & & .217 & Accepted \\
CFR \& TD/TA & $2^{\text {nd }}$ & -1.50231 & -1.328 & .983 & Accepted \\
CFR \& TD/SE & $2^{\text {nd }}$ & 0.00399 & .022 & \\
\hline
\end{tabular}

Source: Derived from DSE and Annual Reports of Sample Firms (1996-2015)

Note: Data have been compiled by researcher and calculations made on SPSS and Statgraphics

For domestic companies, it is seen that null hypothesis is rejected in cases of both TD/TA and TD/SE as $p$ value is less than 0.05. It means that financial leverage ratios have significant influence on firm's cash flow.

For MNCs it is seen that null hypothesis is accepted in cases of both TD/TA and TD/SE as $\mathrm{p}$ value is more than 0.05 . It means that financial leverage ratios do not have significant influence on firm's cash flow.

\section{Conclusion}

The current study exhibits mixed relationship between CFR and financial leverage ratios. Firms are strongly advised to compare the marginal benefit of using debt with the marginal costs of debt before using it in financing their operations. For a particular change in debt ratio, MNCs' cash flow ratio has been found more sensitive than that of domestic companies. Domestic companies should increase debt ratio and reduce debt equity ratio to enhance CFR. On the other hand, the situation is reversed in case of MNCs. Financial managers of the firms should try to ascertain the optimal capital structure to be adopted as a policy in order to create a balance in satisfying the shareholders' desire and management of capital structure. Further research can be undertaken on impact of financial leverage on firm's value and financial risk.

\section{Appendix}

Table A1. Test of Stationarity of Variables (Domestic Companies).

\begin{tabular}{|c|c|c|c|c|c|c|}
\hline \multirow[b]{2}{*}{ Name of variable } & \multicolumn{2}{|l|}{ Original value } & \multicolumn{2}{|l|}{ First difference } & \multicolumn{2}{|l|}{ Second difference } \\
\hline & ADF Test statistic & $\begin{array}{l}\text { P value of test } \\
\text { statistic }\end{array}$ & ADF Test statistic & $\begin{array}{l}\text { P value of test } \\
\text { statistic }\end{array}$ & ADF Test statistic & $\begin{array}{l}\text { P value of test } \\
\text { statistic }\end{array}$ \\
\hline CFR & -3.5122 & 0.0683 & -3.62293 & 0.05813 & -5.13201 & 0.004536 \\
\hline FS & -4.18004 & 0.02065 & -4.28288 & 0.0182 & -3.29792 & 0.0102 \\
\hline SG & -3.9409 & 0.03197 & -5.40624 & 0.002454 & -5.36091 & 0.00307 \\
\hline Tan & -2.12797 & 0.4973 & -4.40377 & 0.01465 & -4.99524 & 0.005721 \\
\hline MEf & -2.89053 & 0.1877 & -4.98578 & 0.00000008 & -5.64464 & 0.000000003 \\
\hline DP & -4.36475 & 0.01468 & -7.39641 & 0.0000089 & -8.35629 & 0.0000036 \\
\hline PO & -3.71966 & 0.04753 & -6.84308 & 0.0001 & -10.8268 & 0.000001 \\
\hline ID & -4.07412 & 0.02508 & -5.35337 & 0.002696 & -5.21329 & 0.003946 \\
\hline NWC & -1.90003 & 0.613 & -5.08594 & 0.004337 & -4.91722 & 0.00653 \\
\hline GDP & -2.37986 & 0.3761 & -3.75226 & 0.04653 & -5.52169 & 0.002337 \\
\hline INF & -2.88899 & 0.1881 & -4.00002 & 0.03015 & -4.9462 & 0.00622 \\
\hline
\end{tabular}




\begin{tabular}{lllllll}
\hline \multirow{2}{*}{ Name of variable } & Original value & \multicolumn{3}{c}{ First difference } & \multicolumn{2}{c}{ Second difference } \\
\cline { 2 - 7 } & ADF Test statistic & $\begin{array}{l}\text { P value of test } \\
\text { statistic }\end{array}$ & ADF Test statistic & $\begin{array}{l}\text { P value of test } \\
\text { statistic }\end{array}$ & ADF Test statistic & $\begin{array}{l}\text { P value of test } \\
\text { statistic }\end{array}$ \\
\hline TD/SE & -2.4399 & 0.3495 & -4.41467 & 0.01437 & -4.67495 & 0.009896 \\
TD/CE & -2.41307 & 0.3612 & -4.23577 & 0.0198 & -4.77285 & 0.008341 \\
\hline
\end{tabular}

Source: Annual Reports of Sample Firms (1996-2015)

Note: Computed on Gretl software. All variables are stationary at first difference as $p$ value $<0.05$. The variable firm age (FAg) becomes constant in first difference and becomes 0 in second difference. So, this variable is ignored.

Table A2. Test of Stationarity of Variables (MNCs).

\begin{tabular}{|c|c|c|c|c|c|c|}
\hline \multirow{2}{*}{$\begin{array}{l}\text { Name of } \\
\text { variable }\end{array}$} & \multicolumn{2}{|c|}{ Original value } & \multicolumn{2}{|c|}{ First difference } & \multicolumn{2}{|l|}{ Second difference } \\
\hline & $\begin{array}{l}\text { ADF Test } \\
\text { statistic }\end{array}$ & $\begin{array}{l}\text { P value of test } \\
\text { statistic }\end{array}$ & $\begin{array}{l}\text { ADF Test } \\
\text { statistic }\end{array}$ & $\begin{array}{l}\text { P value of test } \\
\text { statistic }\end{array}$ & ADF Test statistic & $\begin{array}{l}\text { P value of test } \\
\text { statistics }\end{array}$ \\
\hline CFR & -3.78268 & 0.04248 & -4.62785 & 0.009806 & -4.7206 & 0.009141 \\
\hline FS & -1.72944 & 0.6954 & -6.01077 & 0.0008396 & -8.80503 & 0.0000023 \\
\hline SG & -4.14224 & 0.02214 & -6.32839 & 0.0004875 & -7.14808 & 0.0001 \\
\hline Tan & -2.11632 & 0.5032 & -2.14603 & 0.4864 & -3.71904 & 0.01124 \\
\hline MSE & -2.04568 & 0.539 & -5.49722 & 0.002089 & -8.78669 & 0.0000024 \\
\hline MEf & -3.52051 & 0.06735 & -6.16657 & 0.0006432 & -8.10416 & 0.0000048 \\
\hline DP & 0.148655 & 0.995 & -3.30656 & 0.09861 & -3.07222 & 0.01417 \\
\hline $\mathrm{PO}$ & -3.07222 & 0.1417 & -5.69046 & 0.001484 & -6.90946 & 0.0001 \\
\hline ID & -2.74486 & 0.2324 & -4.59474 & 0.01041 & -5.91757 & 0.00119 \\
\hline NWC & -2.07353 & 0.5248 & -3.72044 & 0.04918 & -4.8189 & 0.00771 \\
\hline GDP & -2.37986 & 0.3761 & -3.75226 & 0.04653 & -5.52169 & 0.002337 \\
\hline INF & -2.88899 & 0.1881 & -4.00002 & 0.03015 & -4.9462 & 0.00622 \\
\hline TD/TA & -1.7191 & 0.7002 & -3.24793 & 0.1085 & -5.70871 & 0.001704 \\
\hline $\mathrm{TD} / \mathrm{SE}$ & -1.39829 & 0.8255 & -2.95371 & 0.1719 & -5.98867 & 0.001056 \\
\hline $\mathrm{TD} / \mathrm{CE}$ & -1.37537 & 0.8326 & -2.6425 & 0.2684 & -5.23042 & 0.003832 \\
\hline
\end{tabular}

Source: Compiled from Annual Reports (1996-2015) Note: Data processed on Gretl software. All variables became stationary at second difference as $\mathrm{p}$ value $<$ 0.05 . The variable firm age (FAg) becomes constant in first difference and becomes 0 in second difference. So, this variable is ignored.

Table A3. Selection of Models.

\begin{tabular}{|c|c|c|c|c|c|c|}
\hline Model No. & Variables removed & R square & Adjusted R square & S. E ofestimate & F statistic & Sig. of $F$ \\
\hline \multicolumn{7}{|c|}{ Model D (CFR) } \\
\hline 1 & None & 1.000 & .996 & .49046 & 298.187 & .003 \\
\hline 2 & SG & .999 & .997 & .45213 & 377.822 & .000 \\
\hline 3 & SG, FS & .999 & 997 & .44816 & 416.520 & .000 \\
\hline \multicolumn{7}{|c|}{ Model M (CFR) } \\
\hline 1 & None & .870 & -.044 & 10.977500 & .952 & .624 \\
\hline 2 & GDP & .869 & .304 & 8.967348 & 1.537 & .404 \\
\hline 3 & GDP, MEf & .868 & .473 & 7.800921 & 2.197 & .233 \\
\hline 4 & GDP, MEf, ID & .867 & .574 & 7.014842 & 2.959 & .121 \\
\hline 5 & GDP, MEf, ID, MSE & .865 & 640 & 6.449457 & 3.842 & .057 \\
\hline 6 & GDP, MEf, ID, MSE, INF & .864 & 690 & 5.987084 & 4.949 & .023 \\
\hline 7 & GDP, MEf, ID, MSE, INF, NWC & .853 & .707 & 5.817359 & 5.824 & .011 \\
\hline 8 & GDP, MEf, ID, MSE, INF, NWC, SG & .837 & .710 & 5.787373 & 6.595 & .006 \\
\hline
\end{tabular}

Source: Compiled from Annual Reports of sample firms (1996-2015) Note: Data processed by SPSS software

Table A4. Test of Multicollinearity Problem in Models D (CFR).

\begin{tabular}{llll}
\hline $\mathbf{1}^{\text {st }}$ difference of Variables & VIF & Measures taken to remove multicollinearity & VIF value after removing multicollinearity \\
\hline Tan & 8.005 & & 3.254 \\
MSE & 2.748 & & 2.435 \\
MEF & 7.115 & & 6.150 \\
DP & 7.239 & & 5.718 \\
PO & 5.102 & 5.083 \\
ID & 12.366 & & 3.756 \\
NWC & 6.700 & & 6.440 \\
GDP & 3.697 & & 3.347 \\
INF & 3.689 & & 3.558 \\
TD/TA & 17.245 & & 6.567 \\
TD/SE & 131.511 & & 3.530 \\
TD/CE & 137.364 & TD/CE Dropped \\
\hline
\end{tabular}

Source: Compiled from Annual Reports (1996-2015) Note: Data processed on Gretl software 
Table A5. Detection and Measures of Multicollinearity Problem in Model M (CFR).

\begin{tabular}{llll}
\hline $\mathbf{2}^{\text {nd }}$ difference of Variables & VIF & Measures taken to remove multicollinearity & VIF value after removing multicollinearity \\
\hline TD/SE & 223.547 & & 2.752 \\
TD/TA & 6.573 & & 5.745 \\
FS & 2.349 & & 2.825 \\
PO & 3.800 & & 1.065 \\
TD/CE & 252.157 & Variable transformed to $2^{\text {nd }}$ difference of reciprocal & 1.083 \\
DP & 2.040 & & 1.212 \\
Tan & 1.200 & & 2.664 \\
\hline
\end{tabular}

Source: Compiled from Annual Reports (1996-2015) Note: Data processed on Gretl software

Table A6. Normality Test of Residuals.

\begin{tabular}{llllllll}
\hline \multirow{2}{*}{ Model No. } & \multicolumn{2}{l}{ Kolmogorov-Smirnov } & \multicolumn{2}{c}{ Shapiro-Wilk } & \multicolumn{2}{c}{ Chi square } \\
\cline { 2 - 8 } & Statistic & df & Sig. & Statistic & df & Sig. & Chi statistic \\
\hline D (CFR) & .142 & 17 & $.200^{*}$ & .951 & 17 & .476 & 1.041 \\
M (CFR) & .193 & 17 & .092 & .936 & 17 & .274 & 1.496 \\
\hline
\end{tabular}

Source: Compiled from Annual Reports (1996-2015) Note: Data processed on SPSS \& Gretl software

Table A7. Breusch-Pagan test of heteroscedasticity.

\begin{tabular}{lllll}
\hline S/L & Name of the model & No. of observations & LM test statistic & p value of LM test statistic \\
\hline 1 & D (CFR) & 17 & 3.925705 & 0.972040 \\
2 & M (CFR) & 17 & 8.856498 & 0.263124 \\
\hline
\end{tabular}

Source: Compiled from Annual Reports (1996-2015)Note: Data processed on Gretl software

Table A8. Test of Autocorrelation.

\begin{tabular}{llllllll}
\hline $\begin{array}{l}\text { Name of the } \\
\text { model }\end{array}$ & DW Stat & P value of DW & $\mathbf{D}_{\mathbf{U}}$ & $\mathbf{D}_{\mathbf{L}}$ & Decision & $\begin{array}{l}\text { Test statistic of } \\
\text { LM }\end{array}$ & $\begin{array}{l}\text { p value of LM } \\
\text { test }\end{array}$ \\
\hline $\mathrm{D}(\mathrm{CFR})$ & 1.036276 & 0.343707 & 3.3782 & 0.1376 & No decision & 2.905912 & 0.163 \\
$\mathrm{M}(\mathrm{CFR})$ & 1.404127 & 0.422726 & 2.5366 & 0.4511 & No decision & 0.845821 & 0.385 \\
\hline
\end{tabular}

Source: Compiled from Annual Reports (1996-2015) Note: Data processed on Gretl software

Table A9. Summary Statistics of the Models.

\begin{tabular}{llllll}
\hline Model No. & R square & Adj. R square & S. E of estimates & F statistic & p value of $\mathbf{F}$ \\
\hline D1(CFR) & 0.996345 & 0.988303 & 0.857019 & 123.8966 & 0.000023 \\
M (CFR) & 0.748905 & 0.553609 & 7.179637 & 3.834719 & 0.032618 \\
\hline
\end{tabular}

Source: Compiled from Annual Reports (1996-2015) Note: Data processed on SPSS \& Gretl software

Table A10. Coefficients of model D (CFR).

\begin{tabular}{llllll}
\hline \multicolumn{2}{l}{ Dependent Variable: 2nd difference of CFR } & & & \\
\hline \multirow{2}{*}{ 2nd differences of variables } & \multicolumn{2}{l}{ Unstandardized Coefficients } & Standardized Coefficients & t & Sig. \\
\cline { 2 - 5 } & B & Std. Error & Beta & -.399 & .706 \\
\hline (Constant) & -.087 & .217 & -.034 & -.702 & .514 \\
Tan & -9.552 & 13.608 & .098 & 2.317 & $.068^{*}$ \\
MSE & 215.385 & 92.957 & -.213 & -3.173 & $.025^{* *}$ \\
MEf & -242.961 & 76.581 & -.426 & -6.589 & $.001^{* * *}$ \\
DP & -12.373 & 1.878 & .342 & 5.618 & $.002^{* * *}$ \\
PO & 30.608 & 5.448 & -.217 & -4.142 & $.009^{* * *}$ \\
ID & -28.968 & 6.994 & 1.001 & 14.586 & $.000^{* * *}$ \\
NWC & 71.368 & 4.893 & .050 & 1.003 & .362 \\
GDP & .375 & .373 & -.713 & -13.975 & $.000^{* * *}$ \\
INF & -1.583 & .113 & .311 & 4.493 & $.006^{* * *}$ \\
TD/TA & 50.161 & 11.163 & -.310 & -6.103 \\
TD/SE & -3.022 & .495 & $.002^{* * *}$ \\
\hline
\end{tabular}

Note: Data processed in SPSS *Significant at $10 \% * *$ Significant at $5 \% * * *$ Significant at $1 \%$ 
Table A11. Coefficients of model M (CFR).

\begin{tabular}{|c|c|c|c|c|c|}
\hline \multicolumn{6}{|c|}{ Dependent Variable: 2nd difference of CFR } \\
\hline \multirow{2}{*}{ 2nddifferences of variables } & \multicolumn{2}{|c|}{ Unstandardized Coefficients } & \multirow{2}{*}{$\begin{array}{l}\text { Standardized Coefficients } \\
\text { Beta }\end{array}$} & \multirow{2}{*}{$\mathbf{t}$} & \multirow{2}{*}{ Sig. } \\
\hline & B & Std. Error & & & \\
\hline (Constant) & -.563 & 1.785 & & -.315 & .760 \\
\hline $\mathrm{TD} / \mathrm{SE}$ & .399 & 18.532 & .006 & .022 & .983 \\
\hline $\mathrm{TD} / \mathrm{TA}$ & -150.231 & 113.150 & -.532 & -1.328 & .217 \\
\hline FS & 84.964 & 43.904 & .543 & 1.935 & $.085^{*}$ \\
\hline Tan & 197.939 & 87.409 & .416 & 2.265 & $.050 * *$ \\
\hline $\mathrm{PO}$ & -218.608 & 73.200 & -.515 & -2.986 & $.015 * *$ \\
\hline DP & 6.056 & 11.628 & .091 & .521 & .615 \\
\hline $1 /(\mathrm{TD} / \mathrm{CE})$ & .045 & .130 & .095 & .347 & .736 \\
\hline
\end{tabular}

Note: Data processed on SPSS *Significant at 10\%**Significant at $5 \%$

\section{References}

[1] Siddiqui, Javed, and M. Zillur Rahman. "A Comparison of Capital Structures among MNCs and Local Companies in Bangladesh." Journal of Business Research 4 (2002): 53-66.

[2] Islam, M. S. and M. M. Islam. "Analysis of Capital Structure \& Profitability: A Case Study of North Bengal Paper Mills Limited" Journal of Business Studies 1, no. 2 (2003): 33-43.

[3] Chowdhury, Anup, and Suman Paul Chowdhury. "Impact of Capital Structure on Firm's Value: Evidence from Bangladesh." Business \& Economic Horizons 3, no. 3 (2010): 111-122.

[4] Islam, M. E., L. Rahman and A. N. M. Shibly Noman Khan. "Influence of Profitability and Risk on Capital Structure: An Analysis on the Cement Industry of Bangladesh" Journal of Banking \& Financial Services 5, no. 2 (2011): 231-44.

[5] Hasan, Md Bokhtiar, AFM Mainul Ahsan, Md Afzalur Rahaman, and Md Nurul Alam. "Influence of Capital Structure on Firm Performance: Evidence from Bangladesh." International Journal of Business and Management 9, no. 5 (2014): 184-94.

[6] Huq, Begum Ismat Ara. "An Analysis of Leverage-A Comparative Analysis of Some Public and Private Sector Chemical Industries in Bangladesh." Business Review 4, no. (1\&2) (July-December 2004): 13-20.

[7] Uddin, Md. Hamid, Md. Zakir Hossain, and Abu Yousuf Md. Abdullah. "An Empirical Study on Capital Structure of the Companies Listed on the Dhaka Stock Exchange." Journal of Business Administration 30, no. 1\&2 (January \& April 2004): 43-60.

[8] Ahmed, Shaheen. "Analysis of Financial Structure for the Measurement of the Performance of Some Selected Insurance Companies of Bangladesh." Journal of Business Studies 2, no. 2 (December, 2004): 91-105.

[9] Modigliani, Franco, and Merton H. Miller. "The Cost of Capital, Corporation Finance and the Theory of Investment." The American Economic Review 48, no. 3 (1958): 261-297.

[10] Lubatkin, Michael, and Sayan Chatterjee. "Extending Modern Portfolio Theory into the Domain of Corporate Diversification: Does it Apply?" Academy of Management Journal 37, no. 1 (1994): 109-136.
[11] Apergis, Nicholas, and John Sorros. "Long-Term Debt and the Value of the Firm, Evidence from International Listed Manufacturing Firms." Review of Economics \& Finance 1 (2011): 60-72.

[12] Muscettola, Marco. "Leverage Risk. The Weight of Borrowed Capital Distinguishes the Solvency of Firms: An Empirical Analysis on a Sample of 4,500 Italian SMEs." International Journal of Economics and Finance 5, no. 12 (2013): 24-39.

[13] Barakat, Abdallah. "The Impact of Financial Structure, Financial Leverage and Profitability on Industrial Companies Shares Value (Applied Study on a Sample of Saudi Industrial Companies)." Research Journal of Finance and Accounting 5, no. 1 (2014): 55-66.

[14] Fama, Eugene F., and Kenneth R. French. "Taxes, Financing Decisions, and Firm Value." The Journal of Finance 53, no. 3 (1998): 819-843.

[15] Park, Kwangmin, and Soo Cheong Jang. "Capital Structure, Free Cash Flow, Diversification and Firm Performance: A Holistic Analysis." International Journal of Hospitality $\begin{array}{llll}\text { Management } & 33 & \text { (2013): }\end{array}$ http://www.elsevier.com/locate/ijhosman (accessed July 8, 2014).

[16] Mansourlakoraj, Roya, and Sahar Sepasi. "Free Cash Flow, Capital Structure and the Value of Listed Companies in Tehran Stock Exchange." International Journal of Management, Accounting and Economics 2, no. 2 (2015): 144-148.

[17] Kordlouie, Hamidreza, Fatemeh Mosadegh, and Hamid Mahdavi Rad. "Impact of Cash Flow on Capital Structure of Firms Listed in Tehran Stock Exchange." American Journal of Business and Management 3, no. 2 (2014): 117-129.

[18] Nahr, Ali Akbar Nonahal, and Zahra Nemati. "Surveying the Relationship between Financial Performance, Free Cash Flow, Capital Structure as well as Related or Unrelated Diversification in Tehran Stock Exchange." Cumhuriyet Science Journal 36, no. 3 (2015): 457-470.

[19] Khan, Asma, Ahmad Kaleem, and Mian Sajid Nazir. "Impact of Financial Leverage on Agency cost of Free Cash Flow: Evidence from the Manufacturing Sector of Pakistan." Journal of Basic and Applied Scientific Research 2, no. 7 (2012): 6694-6700.

[20] Soumaya, Hechmi. The Effect of Debt, Firm Size and Liquidity on Investment -Cash Flow Sensitivity. International Journal of Accounting and Financial Reporting 2 no. 2(2012)1-16. 